\title{
Laparoskopik Matür Kistik Teratom Eksizyonu Sonrası Kistin Büyüklüğü ile İçerdiği Farklı Mezodermal ve Ektodermal Doku Komponentleri Arasındaki İlişki
}

\author{
Adnan ORHAN ${ }^{1}$, Ișıl KASAPOĞLU ${ }^{1}$, Şeyda ARIK ${ }^{2}$, Fatma ÖZ ATALAY ${ }^{3}$, \\ Kemal ÖZERKAN ${ }^{1}$, Bilge ÇETINKAYA DEMIR ${ }^{1}$, Hamza Furkan ŞEN ${ }^{1}$, \\ Gürkan UNCU ${ }^{1}$
}

1 Bursa Uludağ Üniversitesi Tıp Fakültesi, Kadın Hastalıkları ve Doğum Anabilim Dalı, Bursa.

2 Bursa Uludağ Üniversitesi Sağlık Bilimleri Enstitüsü, Tıp - Biyoistatistik Anabilim Dalı, Bursa.

3 Bursa Uludağ Üniversitesi Tıp Fakültesi, Tıbbi Patoloji Anabilim Dalı, Bursa.

\section{ÖZET}

Overin matür kistik teratomu (MKT) ikinci ve üçüncü dekattaki kadınların en sık görülen over tümörüdür. Hemen tamamı benign olan bu tümörlerin rüptür, torsiyon ve malignite gibi çeşitli komplikasyonları vardır. Her üç germ yaprağından da köken alabilen bu tümörlerde kemik, kıkırdak, diş gibi farklı germ yapraklarına ait dokular izlenebilir. Bu çalışmanın amacı laparoskopik MKT eksizyonu yaptığımız hastaların tümör iceriklerindeki doku farklılıklarını gözlemek ve bu dokuların MKT kist büyüklüğ̈̈ ile olan iliskisini araștırmaktır. Retrospektif olarak planlanan bu çalışmaya 01.01.2006 - 31.12.2018 tarihleri arasında bir üniversite hastanesinde laparoskopik MKT eksizyonu uygulanan hastalar alındı. Hastaların demografik özellikleri, MKT çapı, bilateralite oranı, lobülasyon, içeriğindeki kıl, diş, kemik dokusu varlığı ayrıntılı olarak incelendi. Çalışmaya 236 hasta alındı. 222 hastaya laparoskopik MKT kist eksizyonu uygulanmıștı. 14 hastada ise diğer laparoskopik operasyonlar sonrasında patoloji spesimeninde matür kistik teratom saptanmıştı. Bilateralite oranı \% 15,2 idi. $4-5 \mathrm{~cm}$ çapında 58, 5-6 cm çapında 78, 6-7 cm çapında 82, 7 cm'den büyük 54 MKT saptandı. MKT'un çapı arttıkça içerisinde kıl, dis veya kemik doku bulunma veya lobule olma ihtimali belirgin olarak artıyordu. İstatistiksel olarak bakıldığında özellikle $7 \mathrm{~cm}$ den büyük kistlerde her üç dokuyu da içerme ve lobülasyon olasılığı en yüksek anlam düzeyine ulaşıyordu. Sonuç olarak laparoskopik MKT eksizyonu yapılan olgularda kist boyutu ile içerdiği farklı germ yapraklarına ait doku komponentleri ve lobülasyon durumu doğru orantılıdır. Bu durum özellikle $7 \mathrm{~cm}$ ve üstü matür kistik teratomlarda daha belirgindir.

Anahtar Kelimeler: Matür kistik teratom. Dermoid kist. Ektodermal komponentler.

The Relationship Between the Size and Ectodermal or Mesodermal Components in Laparoscopic Mature Cystic Teratoma Excisions

\begin{abstract}
Mature cystic teratoma of the ovary (Dermoid cyst) is the most common ovarian tumor in women in the second and third decades. These tumors, all of which are benign, have various complications such as rupture, torsion, and malignancy. They can be derived from all three germ leaves and have different mesodermal and ectodermal tissue components such as hair, bone, and teeth. This study aimed to investigate the differences of mesodermal and ectodermal tissue components in mature cystic teratoma contents of the patients undergoing laparoscopic excision and to investigate the relationship between these tissue components and the tumor size. Patients who underwent laparoscopic mature cystic teratoma cyst excision in a university hospital in Bursa, Turkey between 01.01.2006 - 31.12.2018 were included in this retrospective study. Demographic characteristics of the patients, the diameter of the mature cystic teratoma cyst, bilaterality, lobulation, presence of hair, teeth, bone, cartilage tissue components in the tumor were evaluated. 236 women were included in the study. 222 patients underwent laparoscopic mature cystic teratoma cyst excision. 14 patients underwent other laparoscopic procedures, and mature cystic teratoma was found in the pathology specimen incidentally. Bilaterality rate was $15.2 \%$. There were 58 mature cystic teratomas in 4-5 cm diameter, 78 in $5-6$ diameter, 82 in 6-7 cm diameter and 54 mature cystic teratomas larger than $7 \mathrm{~cm}$. As the diameter of the mature cystic teratoma increased, the presence of hair, teeth, or osseous tissue component or lobulation of the tumor increased significantly. In mature cystic teratomas larger than $7 \mathrm{~cm}$, the possibility of including all three tissue components and lobulation reached the highest level of statistical significance. In conclusion, the size of the mature cystic teratoma and ectodermal tissue components of the tumor are proportional in laparoscopic mature cystic teratoma cyst excision procedures.
\end{abstract}

Key Words: Mature cystic teratomab Dermoid cyst. Ectodermal components.

Geliş Tarihi: 14 Nisan 2019

Kabul Tarihi: 29 Ağustos 2019

Dr. Adnan ORHAN

Bursa Uludağ Üniversitesi Tıp Fakültesi,

Kadın Hastalıkları ve Doğum Anabilim Dalı, Bursa.

Tel.: 05056337102

e-posta: adnanorhan@uludag.edu.tr
Overin matür kistik teratomu (MKT) ya da jinekologlar arasında daha yaygin bilinen ismiyle "Dermoid Kist" her üç germ yaprağından da köken alabilen kistik kitlelerdir ${ }^{1}$. Tüm over tümörleri göz önüne alındığında sadece \%15'ini matür kistik teratomlar oluştururken ikinci ve üçüncü dekattaki kadınlarda en sık 
görülen benign over tümörleri matür kistik teratomlardir ${ }^{2}$. Siklıkla asemptomatik olan MKT'lar genellikle başka bir nedenle yapılan tetkikler esnasında veya jinekolojik operasyonlar esnasında insidental olarak saptanırlar. Nadiren bulgu verdiklerinde ise ovarian torsiyon, menstrüel düzensizlik, karın ve kasık ağrısı gibi belirtilerle prezente olabilirler. Yaklaşık olarak \%15-20 oranında bilateral olarak ta bulunabilirler ${ }^{3}$.

Matür kistik teratomların bir üst sınıfı olan teratomlar pluripotent orijinli germ hücrelerinden köken alan ve hem matür hem de immatür dokulara ait içerik bulunduran tümörlerdir ${ }^{4}$. MKT'ların nasıl bir etyopatogenez ile geliştiği henüz net olarak aydınlatılamamış olsa da oosit içerisindeki genetik materyalin ikinci polar cisimcik atılımındaki bir probleden kaynaklandığı ve bu durumun kendi kendine fertilizasyonu (Self fertilization) tetiklediği hipotezi üzerinde durulmaktadır ${ }^{5}$.

MKT içeriği çok farklı ektodermal doku komponentleri içerebilmesi nedeni ile çok şaşırtıcı olabilmektedir. Saç, k1l, diş, kemik gibi ektodermal dokular kas, yağ ve kıkırdak gibi mezodermal dokular ve silyalı epital gibi endodermal dokular matür kistik teratomlar içerisinde bulunabilir. Bu kadar farklı dokuları içermelerine rağmen diferansiasyon ve hızlı büyüme yetenekleri çok sınırlıdır. Bundan dolayı MKT'ların malignite potansiyeli \%1-2 düzeyinde kalmaktadır ${ }^{6}$. En çok ektodermal orijinli dokuları içerdiklerinde skuamöz hücreli kanser MKT'dan en sık gelişen malign tümör tipidir $^{7}$.

Matür kistik teratomların laparoskopik cerrahisinde uygun cerrahi klivaj bulunarak diseksiyonunun tamamlanması ve bir endoskopik torba aracılığı ile batın dışına alınması artık hemen her matür kistik teratom için altın standart tedavidir ${ }^{8}$. Laparoskopik MKT eksizyonu sonrası bu tür doku komponentleri içeren kistlerin batın dışına alınması endoskopik torba ile bile olsa zor olmaktadır. Özellikle kemik, kıkırdak ve diş gibi esnemeyen sert ektodermal ve mezodermal dokular MKT içeriği büyüdükçe trokardan batın dışına alınırken zorluk çıkartırlar ${ }^{9}$. Biz bu çalışmada laparoskopik MKT eksizyonu sonrasında kistin çapı ile kist içeriğindeki farklı ekzodermal ve mezodermal doku komponentleri arasındaki ilişkiyi araştırdık.

\section{Gereç ve Yöntem}

Bu çalışma Bursa'da bir Üniversite Tıp Fakültesi Hastanesi Kadın Hastalıkları ve Doğum Ana Bilim Dalında retrospektif olarak planlandı. Çalışmaya 01.01.2006 - 31.12.2018 tarihleri arasında laparoskopik ovaryan MKT eksizyonu uygulanan hastalar ile başka bir benign jinekolojik patoloji endikasyonu ile laparoskopi uygulanan ve operasyon esnasında MKT saptanan hastalar alındı. Hastaların yaş, vucut kitle indeksi, parite, geliş semptomu, bilateralite oranı, operasyon süresi, operasyon komplikasyonu, kimyasal peritonit varlığı gibi demografik özellikleri kaydedildi. Çıkartılan matür kistik teratom içeriğindeki kıl (ektoderm), diş (ektoderm) ve kemik (mezoderm) gibi farklı ektodermal ve mezodermal dokularının varlığı saptand1. Kitlenin ikiden fazla lobülasyon gösterip göstermediği değerlendirildi. MKT büyüklüğü ile içerdiği farklı doku komponentleri arasında bir ilişkinin olup olmadığ incelendi. Aynı zamanda MKT çapı ile her üç doku komponentini de aynı anda içerme olasılı̆̆ 1 arasındaki ilgileşim incelendi.

Bir retrospektif değerlendirme olmasına rağmen çalışma ile ilgili olarak Uludağ Üniversitesi Tıp Fakültesi klinik araştırmalar etik kurulu onayı alındı (20195/18). Çalışmaya alınma kriterleri olarak kliniğimizde laparoskopik MKT eksizyonu yapılan hastalar ile benign jinekolojik endikasyonlar ile laparoskopi uygulanıp MKT saptanan hastalar seçildi. Malignite ihtimali olan hastalar ve permanent patoloji sonucu MKT’dan farklı çıkan hastalar çalışma dışı bırakıldı.

\section{İstatistiksel Analiz}

Sonuçların istatistiksel değerlendirilmesi, SPSS (Statistical Package for Social Sciences 23.0 for Windows) programı kullanılarak yapıldı. Değişkenlerin normal dağılım gösterip göstermediğini değerlendirmek için Shapiro Wilk testi kullanıldı. Yaş ve vücut kitle indeksi gibi tanımlayıcı istatistikler, ortanca (minimum: maksimum), kategorik değişkenler $\mathrm{n}(\%)$ olarak bildirildi. Kategorik değişkenlerin biyoistatistiksel karşılaştırılmasında Pearson ki-kare testi kullanıldı. P değeri 0.05 altında saptandığında istatistiksel olarak anlamlı kabul edildi.

\section{Bulgular}

Toplamda 236 hastanın verileri retrospektif olarak analiz edildi. Olguların ortalama yaşı 26,5 ortalama vücut kitle index'leri 21,5’ti. 222 hastaya (\%94,1) MKT endikasyonu ile laparoskopik eksizyon yapılmıştı. Geriye kalan 14 hastaya $(\% 5,9)$ ise benign jinekolojik endikasyonlar nedeni ile laparoskopik bir operasyon uygulanırken insidental olarak MKT saptanmıştı. 200 hastada unilateral MKT vardı. 36 hastada ise bilateral MKT vardı. Toplamda 272 adet MKT değerlendirildi ve bilateralite oranı \%15,2 olarak saptand1. Laparoskopik MKT eksizyonu uygulanan hastaların 12'sinde $(\% 5,2)$ ovaryan torsiyon nedeni ile acil olarak laparoskopi uygulanmıştı. Laparoskopi esnasında 11 hastada $(\% 4,6)$ matür kistik teratom içeriği ideal cerrahi diseksiyon alanı ve klivajı bulunmasına rağmen patladı ve batına kist içeriği bir miktar yayıldı. Fakat bu hastaların hiçbirinde kimyasal peritonit tablosu gelişmedi. Hiçbir matür kistik teratomda maligniteye rastlanmadi. Ortalama operasyon zamanı 65,6 dakika olarak saptandı. Olguların demografik, klinik ve operatif verileri Tablo-I'de sunulmuştur. 
Tablo I. Demografik Veriler

\begin{tabular}{|c|c|}
\hline \multicolumn{2}{|l|}{$\mathrm{N}=236$ hasta } \\
\hline Yaş (Yıl, ort..SD) & $26,5 \pm 2,34$ \\
\hline Vücut Kitle indeksi (kg/m², ort. $\pm S D)$ & $21.5 \pm 4,87$ \\
\hline Parite ( $\geq 1)$ & $56(\% 23,7)$ \\
\hline \multicolumn{2}{|l|}{ Operasyonun Şekli } \\
\hline $\begin{array}{l}\text { - Laparoskopik Dermoid kist (Matür kistik } \\
\text { Teratom) eksizyonu }\end{array}$ & $222(\% 94,1)$ \\
\hline $\begin{array}{l}\text { - Laparoskopik benign cerrahi (Histerekto- } \\
\text { mi, Oooferektomi vs.) }\end{array}$ & $14(\% 5,9)$ \\
\hline Unilateralite (\%) & $200(\% 84,8)$ \\
\hline Bilateralite (\%) & $36(\% 15,2)$ \\
\hline \multicolumn{2}{|l|}{ Asıl Başvuru Semptomu (\%) } \\
\hline - Ağrı & $82(\% 34,7)$ \\
\hline - Menstrüel düzensizlik & $128(\% 54,2)$ \\
\hline - Torsiyon & $12(\% 5,2)$ \\
\hline - İnsidental saptanma & $14(\% 5,9)$ \\
\hline Operasyon esnasında rüptür (Spillage) (\%) & $11(\% 4,6)$ \\
\hline Operasyon zamanı (dakika) & $65.6(38-92)$ \\
\hline
\end{tabular}

Veriler median (minimum-maksimum) veya $n(\%)$ olarak ifade edilmiştir.

236 hastadan toplamda elde edilen MKT sayıs 272'ydi. Matür kistik teratomun boyutu ile içerdiği ektodermal ve mezodermal doku komponentleri arasındaki ilişkiyi saptamak için kistin boyutu 4-5 cm, 5$6 \mathrm{~cm}, 6-7 \mathrm{~cm}$ ve $7 \mathrm{~cm}$ ve üstü şeklinde 4 ayrı sınıfta incelendi (Tablo-II). Her matür kistik teratomun k1l, kemik ve diş dokusu içerip içermediği hesaplandı. Buna göre matür kistik teratomun boyutu arttıkça içerisinde kıl, kemik ve diş gibi ektodermal veya mezodermal komponentleri ayrı ayrı içerme olasılığ istatistiksel olarak anlamlı düzeyde artmaktaydı. Alt grup analizlerinde bu farkın özellikle $7 \mathrm{~cm}$ ve üstü matür kistik teratomlarda istatistiksel olarak anlaml düzeye ulaştığı görüldü.

Tablo II. Matür kistik teratomun boyutu ile içerdiği ektodermal (Kıl, diş) veya mezodermal (Kemik) doku komponentleri arasındaki ilişki

\begin{tabular}{|c|c|c|c|c|c|c|}
\hline & \multicolumn{2}{|c|}{$\begin{array}{c}\text { Ektodermal Kıl } \\
\text { Komponenti }\end{array}$} & \multicolumn{2}{|c|}{$\begin{array}{c}\text { Ektodermal Diş } \\
\text { Komponenti }\end{array}$} & \multicolumn{2}{|c|}{$\begin{array}{l}\text { Mezodermal } \\
\text { Kemik } \\
\text { Komponenti }\end{array}$} \\
\hline & Var & Yok & Var & Yok & Var & Yok \\
\hline $\begin{array}{l}\text { 4-5 cm çapındaki } \\
\text { matür kistik } \\
\text { teratomlar }(n=58)\end{array}$ & $\begin{array}{c}7(10.1 \\
0 \%)\end{array}$ & $\begin{array}{c}51(25.1 \\
0 \%)\end{array}$ & $\begin{array}{c}5(7.90 \% \\
)\end{array}$ & $\begin{array}{c}53(25.40 \\
\%)\end{array}$ & $\begin{array}{c}6(8.70 \\
\%)\end{array}$ & $\begin{array}{c}52(25.60 \\
\%)\end{array}$ \\
\hline $\begin{array}{l}5-6 \mathrm{~cm} \text { çapındaki } \\
\text { matür kistik } \\
\text { teratomlar }(n=78)\end{array}$ & $\begin{array}{c}10(14 . \\
50 \%)\end{array}$ & $\begin{array}{c}68(33.5 \\
0 \%)\end{array}$ & $\begin{array}{c}7(11.10 \\
\%)\end{array}$ & $71(34 \%)$ & $9(13 \%)$ & $69(34 \%)$ \\
\hline $\begin{array}{l}\text { 6-7 cm çapındaki } \\
\text { matür kistik } \\
\text { teratomlar }(n=82)\end{array}$ & $\begin{array}{c}14(20 . \\
30 \%)\end{array}$ & $\begin{array}{c}68(33.5 \\
0 \%)\end{array}$ & $\begin{array}{c}12(19.1 \\
0 \%)\end{array}$ & $\begin{array}{c}70(33.50 \\
\%)\end{array}$ & $\begin{array}{c}14(20.3 \\
0 \%)\end{array}$ & $\begin{array}{c}68(33.50 \\
\%)\end{array}$ \\
\hline $\begin{array}{l}7 \mathrm{~cm} \text { üstü } \\
\text { matür kistik } \\
\text { teratomlar }(n=54)\end{array}$ & $\begin{array}{c}38(55 . \\
10 \%)\end{array}$ & $\begin{array}{c}16(7.90 \\
\%)\end{array}$ & $\begin{array}{c}39(61.9 \\
0 \%)\end{array}$ & $\begin{array}{c}15(7.20 \\
\%)\end{array}$ & $\begin{array}{c}40(58 \% \\
\quad)\end{array}$ & $\begin{array}{c}14(6.90 \\
\%)\end{array}$ \\
\hline p-değeri & & .001 & & .001 & & .001 \\
\hline
\end{tabular}

Veriler $n(\%)$ olarak ifade edilmiştir.

Not: Alt grup analizlerinde $7 \mathrm{~cm}$ ve üstü matür kistik teratomların bütün diğer boyutlardaki kistlere göre ayrı ayrı kıl, diș veya kemik doku içerme ihtimali istatistiksel olarak anlamlı düzeyde artmıştı.
MKT'un boyutu arttıkça her üç farklı ektodermal ve mezodermal doku komponentini de aynı anda içerme olasılığının artıp artmadığını ve yine MKT'un boyutu arttıkça ikiden fazla lobül içerme olasılığının artıp artmadığı Tablo-III'de değerlendirildi. Buna göre MKT'un boyutu arttıkça kıl, diş ve kemik ektodermal ve mezodermal komponentlerinin üçünü de birden aynı anda içerme olasılığı istatistiksel olarak anlamlı düzeyde artmaktaydı. Aynı durum lobülasyon içinde geçerliydi. MKT'un boyutları arttıkça ikiden fazla lobül içerme olasılığı istatistiksel olarak anlamlı düzeyde artmaktaydı. Alt grup analizlerinde bu farkın en fazla hangi boyutta olduğuna bakıldığında ise $7 \mathrm{~cm}$ ve üstü MKT'larda kıl, kemik ve diş komponentlerini birlikte ve aynı anda içerme olasılığının diğer boyutlardaki MKT'lara göre en yüksek istatistiksel anlama kavuştuğu izlendi. Aynı şekilde $7 \mathrm{~cm}$ ve üstü MKT'larda ikiden fazla lobülasyon gösterme olasıl1ğının diğer boyutlardaki MKT'lara göre en yüksek istatistiksel anlama kavuştuğu izlendi.

Tablo III. Matür kistik teratomun boyutu ile kıl, kemik ve diş gibi farklı germ yapraklarından kaynaklanan dokuları aynı anda içerme olasılığının incelenmesi (Birinci sütun) ve matür kistik teratomun boyutu ile ikiden fazla lobül bulundurma olasılığının incelenmesi (İkinci sütun)

\begin{tabular}{|c|c|c|c|c|}
\hline & \multicolumn{2}{|c|}{$\begin{array}{c}3 \text { komponenti içerme } \\
\text { durumu }\end{array}$} & \multicolumn{2}{|c|}{$\begin{array}{c}\text { İkiden fazla lobül } \\
\text { bulundurma durumu }\end{array}$} \\
\hline & Var & Yok & Var & Yok \\
\hline $\begin{array}{l}4-5 \mathrm{~cm} \text { çapındaki } \\
\text { matür kistik teratom- } \\
\text { lar }(n=58)\end{array}$ & 0 & $58(26.10 \%)$ & $3(3.40 \%)$ & $55(29.90 \%)$ \\
\hline $\begin{array}{l}\text { 5-6 cm çapındaki } \\
\text { matür kistik teratom- } \\
\text { lar }(n=78)\end{array}$ & $5(10 \%)$ & $73(32.90 \%)$ & $8(9.10 \%)$ & $70(38 \%)$ \\
\hline $\begin{array}{l}\text { 6-7 cm çapındaki } \\
\text { matür kistik teratom- } \\
\text { lar }(n=82)\end{array}$ & $11(22 \%)$ & $71(32 \%)$ & $25(28.40 \%)$ & $57(31 \%)$ \\
\hline $\begin{array}{l}7 \mathrm{~cm} \text { ve üstü } \\
\text { matür kistik teratom- } \\
\text { lar }(n=54)\end{array}$ & $34(68 \%)$ & $20(9 \%)$ & $52(59.10 \%)$ & $2(1.10 \%)$ \\
\hline p-değeri & & 0.001 & $<0$. & 001 \\
\hline
\end{tabular}

Veriler $n(\%)$ olarak ifade edilmiştir.

Not: Alt grup analizlerinde $7 \mathrm{~cm}$ ve üstü matür kistik teratomların bütün diğer boyutlardaki kistlere göre aynı anda $\mathrm{kll}$, diş veya kemik dokularını içerme ihtimali istatistiksel olarak anlamlı düzeyde artmıştı. Aynı şekilde $7 \mathrm{~cm}$ ve üstü matür kistik teratomların bütün diğer boyutlardaki kistlere göre ikiden fazla lobile olma durumu istatistiksel olarak anlamlı düzeyde artmışt .

\section{Tartışma ve Sonuç}

$\mathrm{Bu}$ araştırma sonucunda laparoskopik cerrahi ile çıkartılan matür kistik teratomların boyutları arttıkça içerdiği kıl, kemik ve diş gibi ektodermal ve mezodermal 


\section{A. Orhan, ark.}

doku komponentlerinin bulunma olasılığının yükseldiğini saptadık. Her ne kadar hem kıl, hem diş hem de kemik dokusunun aynı anda olma olasılığı ile matür kistik teratomun boyutu arasında da bir orantı saptanamasa da bu dokuların tek tek artışı ile MKT boyutu arasında bir doğru orantı mevcuttu.. Yine benzer şekilde matür kistik teratomlarda boyut arttıkça, tümörün lobule olma olasılığ 1 artıordu. En önemli istatistiksel fark ise $7 \mathrm{~cm}$ ve üstü matür kistik teratomlarda gözlendi.

Matür kistik teratomlar her üç germ yaprağından köken alan benign içerikli ovaryan germ hücreli tümörlerdir $^{10}$. Jinekolojik operasyonlar esnasında veya farkl batın görüntüleme teknikleri esnasında insidental olarak saptanmaları söz konusu olabilir ${ }^{11}$. Tıbbi literatürde \%5-12 oranında insidental saptanan matür kistik teratom oranından bahsetmekte iken, bizim serimizde bu oran $\% 5,9$ olarak saptand 1 .

Her ne kadar overin bilateralite gösteren tümörleri içerisinde yer alsa da matür kistik teratomların bilateralite oranları \%20'yi geçmemektedir ${ }^{12}$. Birçok farkl çalışma da farklı bilateralite oranları bildirilmekle beraber matür kistik teratomlarda bilateralite oranı \%9-18 arasında değişmektedir. Bizim çalıșmamızda bilateralite oranını \%15,2 olarak saptadık. Matür kistik teratomların bilateral olması ile içerdiği mezodermal ve ektodermal doku komponentlerin fazlalığı veya azlığı arasında ise bir ilişki saptamadık.

Ovaryan torsiyon reprodüktif dönemdeki kadınlarda en sık görülen jinekolojik acillerdendir. Matür kistik teratomlarda da sıklıkla torsiyon görülmekle beraber bunun MKT kaynaklı bir patoloji mi olduğu yoksa matür kistik teratomun olayın bir sonucu mu olduğu aslında net değildir ${ }^{13}$. Birçok çalışmada \%5-10 düzeylerinde olan ovaryan torsiyon oranını kendi çalışmamizda da \%5,2 olarak saptadik. Torsiyon izlenen olgular tek tek değerlendirildiğinde MKT boyutunun artması ile torsiyon arasında istatistiksel anlam düzeyine ulaşan bir bulguya rastlamadık.

Matür kistik teratomların preoperatif dönemde rüptürü son derece nadirdir ${ }^{14}$. Bizim serimizde preoperatif dönemde rüptür hiç yokken peroperatif laparoskopik diseksiyon esnasında 11 hastada matür kistik teratom içeriği açılarak batına tümörün yağlı içeriği yayıldı. "Spillage" olarak değerlendirilen bu durumlarda kimyasal peritonit açısından uyanık durumda olmak ve yakın klinik bulgu takibi yapmak son derece önemlidir. Operasyon anında bu olgularda diseksiyon ve klivaj hattı net olarak bulunduğundan kist içeriği tamamen boşalmadan tümör batın dışına alındı, batın $2000 \mathrm{cc}$ 1lık serum fizyolojik ile yıkandı ve hiçbir vakada kimyasal peritonit komplikasyonu izlenmedi.

Matür kistik teratomdan gelişen bir diğer komplikasyon malignitelerdir ${ }^{15}$. Matür kistik teratomlardan malignite gelişme olasılığı çok düşük olmasına rağmen literatürde skuamoz hücreli karsinomdan malign melanoma, gonadoblastomdan adenokarsinoma birçok farklı malign tümör gelişimi bildirilmiştir ${ }^{16}$. Bu tümörler hemen tamamen postmenapozal hastalarda ortaya çıkar. Bizim serimizde 236 hastanın hiçbirinde malign transformasyon izlenmedi. Bunun en büyük nedeni postmenpozal hasta sayısının çok az olması ve hastaların ortalama yaşının 26,5 olması olabilir. Her ne kadar matür kistik teratomdan skuamöz hücreli kanser gelişme ihtimali diğer kanser tiplerinden daha sık olsa da teorik olarak her üç germ yaprağına ait hücrelerden farklı tipte kanserler gelişebilir. Malign transformasyon oranı \%1'i geçmemektedir. Ca 125 başta olmak üzere ovarian malignitelerin hiçbir tümör belirteci matür kistik teratomların malign transformasyonunda kullanılmamaktadır.

Matür kistik teratomlar embriyolojik gelişim basamakları içerisinde her üç germ yaprağından da köken alabilmeleri nedeni ile çok farklı mezodermal ve ektodermal doku komponentlerini içerebilmektedirler. Özellikle ektodermal doku komponentleri olan epidermoid bileşenler, deri dokusu ve sebase glandlar hemen her MKT patolojisinde olabilen patolojik yap1lardır ${ }^{17}$. Diğer daha büyük mezodermal ve ektodermal doku komponentleri olan kemik, diş kıkırdak ve kıl dokuları gibi dokular da matür kistik teratomun içeriğinde yer alabilir. Hengi mezodermal veya ektodermal dokunun hangi MKT içerisinde oluştuğu, bütün mezodermal veya ektodermal doku içeriklerinin bir MKT olgusunda bulunması için ne gibi bir gerekliliğin olduğu, matür kistik teratomun lobüle olması, büyümesi, boyutlarının artması ile içeriğindeki mezodermal veya ektodermal doku tabakaları ile ilgili herhangi bir ilişkinin olup olmadığ leyen sorular arasındadır. Büyüyen ve boyutları artan bir tümörde tümör anjiyogenezi ve hiperplazisine bağlı olarak ileri boyutlarda bir farklılaşma olması beklenebilir. Fakat MKT boyutundaki bu büyüme ve farklılaşmanın içerdiği doku bileşenleri ile ilişkisi olup olmadığı henüz ortaya konulmamıştır.

Her ne kadar MKT ların birçok hastada asemptomatik olmasına rağmen bizim çalışmada hastaların yüzde otuzundan fazlasında ağrı saptanmıştı. Tıbbi literatürde temel başvuru semptomunun ağrı olduğu MKT olguları yaklaşık olarak \%20 düzeylerindedir ${ }^{18}$. Ağr1 şikâyeti ile başvuran MKT hastaları irdelendiğinde sıklıkla bu hastaların ağrı diye tarifledikleri semptomun dismenore olduğu saptandı. Her iki semptomun MKT nedeni ile mi hastada olduğu bilinemese de bu durumun MKT'ye sekonder gelişen dismenore olduğunu düşünmekteyiz.

$\mathrm{Bu}$ çalışmada on iki yıllık bir süre içerisinde tersiyer bir merkezden çıkan MKT olgularının retropektif analiz yapılmış ve tümörün boyutunun artmasının içerdiği mezodermal veya ektodermal doku komponentlerinin fazlalığıyla ve lobülasyon göstermesi ile doğrudan bağlantılı olduğu gösterilmiştir. $\mathrm{Bu}$ ilişki MKT boyutu özellikle $7 \mathrm{~cm}$ ve üstüne çıktığında istatistiksel olarak anlamlı düzeye ulaşıyordu. Laparosko- 


\section{Matür Kistik Teratom ve İçerdiği Farklı Dokular}

pik MKT eksizyonu operasyonlarında özellikle diș, kemik ve kıl gibi mezodermal ve ektodermal orijinli dokuların olduğu tümörleri dikkatli bir şekilde patlatmadan ve saçılmadan batın dışına alırken bu bilgi jinekolog endoskopiste yol gösterebilir. Matür kistik teratomun boyutu $7 \mathrm{~cm}$ 'yi geçtikçe daha fazla yabancı doku içereceğinden ve daha fazla lobülasyon içereceğinden dolayı çok daha dikkatli davranmak operasyonun komplikasyonsuz ve güvenli yapılmasını sağlayabilir.

\section{Teşekkür}

Yazarlar verilerin hastane bilgi yönetim sisteminden alınması esnasında yardımları bulunan tüm asistan doktor ve diğer personele teşekkür ederler. Ayrıca biyoistatistiksel analizlerin son kontrolünde yardımlarından dolayı Biyoistatistik Ana Bilim Dalı'na teşekkür ve şükranlarımızı sunarız.

\section{Kaynaklar}

1. Stany MP, Hamilton CA. Benign disorders of the ovary. Obstet Gynecol Clin North Am 2008;35:271-284.

2. Templeman CL1, Hertweck SP, Scheetz JP, Perlman SE, Falla $\mathrm{ME}$. The management of mature cystic teratomas in children and adolescents: a retrospective analysis. Hum Reprod. 2000 Dec;15(12):2669-72.

3. Kahraman K, Tulek F, Taskın S, Tolunay E, Dokmeci F. Overyan matür kistik teratomlar: 83 olgunun analizi. Türk Jinekoloji Onkoloji Dergisi 2010;4:97-102.

4. Saba L, Guerriero S, Sulcis R, Virgilio B, Melis G, Mallarini G Mature and immature ovarian teratomas: CT, US and MR imaging characteristics. European Journal of Radiology 2009;72:454-463.

5. Linder D, McCaw B, Hecht F. Parthenogenic Origin of Benign Ovarian Teratomas. N Engl J Med. 1975 Jan 9;292(2):63-6.

6. Peterson WF. Malignant degeneration of benign cystic teratomas of the ovary; a collective review of the literature. Obstet Gynecol Surv 1957;12:793-830.

7. Hackethal A, Brueggmann D, Bohlmann MK, Franke FE, Tinneberg HR, Münstedt K. Squamous-cell carcinoma in matu- re cystic teratoma of the ovary: systematic review and analysis of published data. Lancet Oncol 2008;9:1173-1180.

8. Ferrari MM1, Mezzopane R, Bulfoni A, Grijuela B, Carminati R, Ferrazzi E, Pardi G. Surgical treatment of ovarian dermoid cysts: a comparison between laparoscopic and vaginal removal. Eur J Obstet Gynecol Reprod Biol. 2003 Jul 1;109(1):88-91.

9. Medeiros LR, Fachel JM, Garry R, Stein AT, Furness S. Laparoscopy versus laparotomy for benign ovarian tumours. Cochrane Database Syst Rev. 2005 Jul 20;(3):CD004751.

10. Caspi B, Lerner-Geva L, Dahan M, Chetrit A, Modan B, Hagay Z, Appelman Z. A Possible Genetic Factor in the Pathogenesis of Ovarian Dermoid Cysts. Gynecol Obstet Invest. 2003;56(4):203-6.

11. Mori Y, Nishii H, Takabe K, Shinozaki H, Matsumoto N, Suzuki K, Tanabe H, Watanabe A, Ochiai K, Tanaka T. Preoperative diagnosis of malignant transformation arising from mature cystic teratoma of the ovary. Gynecol Oncol. 2003 Aug;90(2):338-41.

12. Ayhan A, Bukulmez O, Genc C, Karamursel BS, Ayhan A. Mature cystic teratomas of the ovary: case series from one institution over 34 years. Eur J Obstet Gynecol Reprod Biol. 2000 Feb;88(2):153-7.

13. Harada M1, Osuga Y, Fujimoto A, Fujimoto A, Fujii T, Yano T, Kozuma S. Predictive factors for recurrence of ovarian mature cystic teratomas after surgical excision. Eur J Obstet Gynecol Reprod Biol. 2013 Dec;171(2):325-8.

14. Caspi B, Appelman Z, Rabinerson D, Zalel Y, Tulandi T, Shoham Z. The growth pattern of ovarian dermoid cysts: a prospective study in premenopausal and postmenopausal women. Fertil Steril. 1997 Sep;68(3):501-5.

15. Kikkawa F, Ishikawa H, Tamakoshi K, Nawa A, Suganuma N, Tomoda Y. Squamous cell carcinoma arising from mature cystic teratoma of the ovary: a clinicopathologic analysis. Obstet Gynecol. 1997 Jun;89(6):1017-22.

16. Kikkawa F, Nawa A, Tamakoshi K, Ishikawa H, Kuzuya K, Suganuma N, Hattori S, Furui K, Kawai M, Arii Y. Diagnosis of squamous cell carcinoma arising from mature cystic teratoma of the ovary. Cancer. 1998 Jun 1;82(11):2249-55.

17. Araujo IB, Pinheiro MV, Zanvettor PH, Studart EJ, Filho DF, Coupland SE. High frequency of malignant transformation of ovarian mature teratoma into squamous cell carcinoma in young patients in northeast Brazil. Int J Gynecol Pathol. 2016 Mar;35(2):176-84.

18. Li C, Zhang Q, Zhang S, Dong R, Sun C, Qiu C, Zhang Z, Yang X, Kong B. Squamous cell carcinoma transformation in mature cystic teratoma of the ovary: a systematic review. BMC Cancer. 2019 Mar 11;19(1):217. 
